\title{
Praising through Intertext. On Jakob Liefer's Literary Technique in the Neo-Latin Epic Bellum Sundense
}

\author{
KONRAD LÖBCKE, PAUL REICHETANZ
}

This paper examines Jakob Liefer's (1571-1655) method of composing a carmen novo modo, that is a combination of laus urbis, epic, and cento. It demonstrates how Liefer systematically employs allusions and citations to turn his account of the historic Margrave War (1308-1317) into a praise of the city of Stralsund and its inhabitants. The analysis focuses on the work's intertextual engagement with the characters and settings of Lucan's Pharsalia and Vergil's Aeneid. Liefer not only borrows from canonical texts to put Stralsund on the same exalted level as Massilia and Troy respectively, but he also modifies his source texts so as to have the heroes before Stralsund surpass the achievements of their literary role models. This technique includes both quantitative and qualitative amplificationes, as the author emphasises not only the scale of Stralsund's military victory but also the humility and Christian piety of its inhabitants.

\section{Introduction}

In 1639, in the midst of the Thirty Years' War, the Protestant priest Jakob Liefer (1571-1655) was forced to leave his parish in Voigdehagen in the northern German region of Pomerania and to seek refuge in the nearby city of Stralsund. Having received a warm welcome and being full of gratitude towards the town's magistrates, Liefer composed the Bellum Sundense (BS), an epic of 1495 lines depicting Stralsund's glorious victory at the end of its last major military conflict some 300 years earlier. ${ }^{1}$ Apart from being one of the most important descriptions

* An earlier version of this paper was presented at the Annual Meeting of Postgraduates in Ancient Literature (Oxford, September 2016). We would like to thank Maria Dreier and Dr. Markus Kersten (University of Basel) for their most valuable input to the present article.

${ }^{1}$ J. Lieferus, Prodromus exhibens bellum Sundense anno MCCCXVI a partu virgineo terra marique gestum, collectum ex Saxonia Chytraei et chronico Pomeraniae manuscripto a Jacobo Liefero pastore Steinhagensi et Vogdehagensi (Rostock, 1639 [USTC 2075127]). For a digitised version, see http://www.vd17.de (14:001341M). The two extant early modern editions (Rostock, 1639; Stralsund, 1715) have been collated and edited with a critical apparatus, historical commentary and a German translation by M. Kruske (ed., tr.), Jakob Liefer, Bellum Sundense. Der Sundische Krieg (Köln, 2004). All 
of the Northern German Margrave War (1308-1317), the Bellum Sundense occupies an extraordinary position in the history of Neo-Latin literature in Pomerania, if not in all of the German regions.

The aim of this paper is to point out the way in which Liefer uses references to classical literature in order to turn his epic into a laus urbis. In two exemplary passages, the author's technique of inserting and manipulating passages taken from Vergil's Aeneid and from Lucan's Pharsalia will be shown to serve the function of rhetorical amplificationes: Liefer adapts his source texts in ways that either quantitatively or qualitatively augment Stralsund's achievements as compared to its literary role models.

\section{Literary and Historical Background of the Bellum Sundense}

The uniqueness of the Bellum Sundense stems from its rare combination of three different literary genres, all of which were popular in Liefer's day: (1) laus urbis, (2) epic, and (3) cento.

(1) As may be seen from the over 200 Neo-Latin city praises attested in the German regions alone, humanist writers valued laudes urbium as an appropriate way to express their gratitude or to ask for future support. ${ }^{2}$ In 1562, the city of Stralsund had already been the subject of an encomium composed by Zacharias Orth, whose influence on the Bellum Sundense, however, has not been established. ${ }^{3}$ At any rate, Liefer follows a safe course of action when he dedicates his poem to the council and the citizens of Stralsund (BS praefatio [henceforth pr.] 1-11), thanks them for giving him refuge (ibid. 72-77), and asks them to provide for his family in the event of his passing away (ibid. 111-115).

quotations of Liefer's work in this paper refer to Kruske's edition. Kruske focuses on the historical background of the Bellum Sundense and does not engage in any detailed discussion of Liefer's literary technique.

2 J. IJsewijn, D. Sacré, Companion to Neo-Latin Studies. Part II. Literary, Linguistic, Philological and Editorial Questions (Leuven, 1998), 46-47.

${ }^{3}$ Z. Orth, Inclytae urbis Stralsundae origo et res gestae, ex veris historiis conscriptae, ad amplissimum senatum populumque Sundensem, a M. Zacharia Ortho Sundensi, poeta laureato (Rostock, 1562 [USTC 666539]). For a discussion of this poem in the literary landscape of sixteenth-century Pomerania, see W. Kühlmann, "Zum Profil des postreformatorischen Humanismus in Pommern. Zacharias Orth (ca. 1535-1579) und sein Lobgedicht auf Stralsund. Mit Bemerkungen zur Gattungsfunktion der laus urbis", in W. Kühlmann, H. Langer (ed.), Pommern in der frühen Neuzeit (Tübingen, 1994), 101123. On the relationship between Liefer and Orth, see Kruske 2004 (as in n. 1), 194. 
(2) In light of the fact that authors of city praises had generally preferred prose over poetry since the twelfth century, it appears somewhat unusual that Liefer chose to compose his Bellum Sundense in hexameters. ${ }^{4}$ Yet, as the epideictic impetus had long been strong in NeoLatin epic, Liefer may be said to have transferred the praise of an individual to that of an entire township. ${ }^{5}$ Remarkably, even his design to praise someone's achievements through the depiction of past, that is medieval, military actions was not unprecedented. As has been shown by Karen Skovgaard-Peterson, the Margaretica of Erasmus Laetus (1525-1582), an epic poem on the Danish Queen Margaret's triumph over the Swedish king in 1389, was intended to make a statement about the Seven Years' War between Denmark and Sweden that had recently been concluded at the time of the work's publication in $1573 .{ }^{6}$ In a similar vein, Liefer wrote in the direct context of the Thirty Years' War, but chose to present the battle for Stralsund as part of the fourteenthcentury Margrave War. ${ }^{7}$

Putting this conflict in the most simplistic terms, we may state that a northern alliance, including both the Danish king Eric and Wizlaus, the ruler of the island of Rügen, fought against a southern alliance led by the ruler of Brandenburg. In 1316, Stralsund - having sided with Brandenburg - was besieged by the Northerners, but its army eventually fought off the attackers and even captured one of the enemies' leaders. For

${ }^{4}$ J.S. Ruth, Urban Honor in Spain. The Laus Urbis from Antiquity through Humanism (Lewiston, NY, 2011), 87. For instance, Rostock, the city of Liefer's alma mater, had been praised in the form of an epideictic oration: J. Possel, Oratio de inclyta urbe Rostochio (Wittenberg, 1560 [USTC 680209]). The text has been edited and complemented with a German translation by N. Thurn (ed., tr.), David Chytraeus, Praecepta rhetoricae inventionis. Vorschriften der Rhetorik. Einleitung, Text und Übersetzung (Rostock, 2000), 293-333.

${ }^{5}$ On "panegyrical epic", see e.g. P. Gwynne, "Epic", in V. Moul (ed.), A Guide to NeoLatin Literature (Cambridge, 2017), 200-220.

${ }^{6}$ K. Skovgaard-Petersen, "Danish Neo-Latin Epic as Anti-Swedish Propaganda", in A. Dalzell, Ch. Fantazzi, R.J. Schoeck (ed.), Acta Conventus Neo-Latini Torontonensis (Binghamton, NY, 1991), 721-727. For other Neo-Latin epics featuring medieval heroes, see C. Kallendorf, "The Neo-Latin Epic", in Ph. Ford, J. Bloemendal, C. Fantazzi (ed.), Brill's Encyclopaedia of the Neo-Latin World. Macropaedia (Leiden - Boston, MA, 2014), 452-456.

${ }^{7}$ For a general introduction to this war, see W. Karge, E. Münch, H. Schmied, Die Geschichte Mecklenburgs. Von den Anfängen bis zur Gegenwart (Rostock, 2011), 25-43. For Stralsund's role in particular, see Kruske 2004 (as in n. 1), 125-183; K. Fritze, "Entstehung, Aufstieg und Blüte der Hansestadt Stralsund", in H. Ewe (ed.), Geschichte der Stadt Stralsund (Weimar, 1984), 9-102, at 48-57. 
Liefer, both the Margrave War and the ongoing Thirty Years' War clearly showed that the power to destroy or to rescue cities and kingdoms ultimately lay with the Christian god only ( $B S$ pr. 64-72).

(3) What sets the Bellum Sundense most clearly apart from contemporary epics and laudes urbium is its peculiar way of engaging with classical literature. In his preface, Liefer ( $B S$ pr. 90-91) calls his work a "carmen $[\ldots]$ novo modo (pleraque enim ex probatis deprompsi autoribus; centonem nomines)" ("a poem of a new kind, for I have borrowed a good deal from the esteemed authors; you might call it a cento"). ${ }^{8}$ It is this novelty of Liefer's literary technique - having his poem oscillate between a cento and an epic ("carmen heroicum", $B S$ pr. 85 ) - which makes the Bellum Sundense stand out among contemporary works. For the sake of illustration, we may consider the work's proem (BS 1-19), which neatly exemplifies the work's overall composition:

Thariadae bellum Moses sanctissimus autor Hebraea scripsit lingua quod gessit Harami ut natum abductum assereret, raptumque cruentis hostium ut ex manibus, dominoque deoque triuni sisteret incolumem praeconem. Scripsit Homerus, mortales multos cuius sapientia vicit, Troianum bellum, Davidis tempore gestum, ut docti statuunt, Graeco antiquissimus autor carmine, et errores varios memoravit Ulyssis Peliden alii cecinere, aut Hectora dixere; Hectora qui Priami natus fortissimus urbem defendens armis patriam, per vulnera mortem mortem adiit foedam, raptatus moenia circum. Arma virumque canens, Troiae qui primus ab oris Italiam fato profugus Lavinaque venit

littora, Virgilius doctus depinxit ad unguem, lingua, quae penetrat iaculo penetrantius omni. Bella per Emathios plus quam civilia campos versibus egregiis depinxit vena Lucani.

${ }^{8}$ All translations of the Bellum Sundense are our own. An ambitious research project on Greek centones has been launched at the Ruhr University Bochum and is due to be completed in spring 2021: https://www.ruhr-uni-bochum.de/griechischecentones/en.html. 
Moses, the most holy author, wrote of Abraham's war in the Hebrew language. He had fought this war in order to free from the enemies' bloody hands the son of Haran, who had been seized and abducted, and to make him the sound herald of the Lord, triune God. [5] Homer, the most venerable author whose wisdom has surpassed many mortals, wrote a Greek song on the Trojan War, fought in the time of David, as is stated by learned men, and he recounted the various wanderings of Ulysses. [10] Others have sung of Achilles or spoken of Hector; Hector, the son of Priam, who was the bravest man to defend his native country by force of arms, and whose wounds made him find a disgraceful death, dragged around the city walls. Singing of arms and the man who, [15] exiled by fate, first came from the coast of Troy to Italy and to Lavinian shores, the man whom sophisticated Vergil portrayed perfectly, in language that penetrates deeper than any spear. Wars more than civil on Emathian plains were depicted through eminent verses by the vein of Lucan.

Even before he points to the war (and the city) at the heart of his work (BS 20-35), Liefer explicitly refers to his literary role models and even goes as far as to extract patches from his classical sources - in this case from the Aeneid (1.1-3a) and the Pharsalia (1.1) - and to integrate them into his own text. Throughout the Bellum Sundense, Liefer makes ample use of this technique, borrowing around 700 of the poem's total number of 1495 lines. His most important role models are indeed Vergil (385 lines) and Lucan (199 lines), followed by Horace, Claudian and Ausonius. ${ }^{9}$ It is worth noting that the original print version of the Bellum

\footnotetext{
${ }^{9}$ Kruske 2004 (as in n. 1), 187-192. The few extant course catalogues of universities in the German Baltic Sea region may hint at the significance of these authors in the sixteenth and seventeenth century, as Liefer himself enrolled at the University of Rostock in 1598. In 1520, the earliest catalogue lists Vergil, Ovid, Catullus, Tibullus, Silius Italicus, and other poets: W. Wagner (ed.), Observantia lectionum in universitate Rostochiensi 1520. Das älteste gedruckte Vorlesungsprogramm der Universität Rostock (Hamburg, 2011), r. 95, 144, 148. In 1565, Ov. Her. and Verg. Ecl. were on the schedule of lectures: see Ordo lectionum quae in academia Rostochiensi proponuntur (Wolfenbüttel, HAB, ms. 95.10 Quodl. 20 (248)). Three years later, Hor. Ars: Series lectionum quae futuro semestri aestivo anni 1568 in academia Rostochiensi publice proponentur (Wolfenbüttel, HAB, ms. 95.10 Quodl. 20 (253)). In 1615, Hor. Sat. and Ep. are relevant: Programma publice propositum quo de suo officio docentes fideliter pollicentur et discentes severe admonentur $[. .$.$] et presenti aestivo semestri proponendis catalogus (Rostock, 1615). Claudian is$ not mentioned before 1662: Ordo lectionum in universitate Rostochiensi hoc anno MDCLXII bono cum deo proponendarum (Rostock University Library, Sondersammlungen, no shelf mark); Ausonius is only referred to in a catalogue of the University of Greifswald in 1624: Series lectionum in universitate Gryphiswaldensi hoc anno MDCXXIV (cum deo) proponendarum (Greifswald, 1624). Lucan is not mentioned at all,
} 
Sundense regularly displays the names of ancient authors in its margins, thus making Liefer's borrowings explicit. These marginal references are accompanied by short summaries of the poem's basic plot in the German vernacular.

Liefer's hesitation to more clearly attach the label of cento to his patchwork poem may be explained with reference to the genre's inventor. Ausonius, in the preface to his cento nuptialis (Cent. 21-25), restricted patches to the maximum length of one and a half lines and did not permit additions to be made by the writer himself. ${ }^{10}$ While the Bellum Sundense thus does not qualify as a cento in the traditional sense, it is very much in line with the less rigid rules adhered to in the sixteenth century, which not only allowed for longer patches but also for lines to be added by the humanist authors themselves and for modifications to be made to their source material. ${ }^{11}$ Liefer takes all these early modern liberties, as he borrows passages of up to ten consecutive lines (see, for instance, BS 251-260, from Aen. 7.341-353), complements his source texts with his own hexameters, and alters individual words and phrases to fit his context. Most significantly to the investigation at hand, modifications of classical texts in the Bellum Sundense are not limited to matters of morphology and syntax (e.g. "arma virumque canens", $B S$ 14), but follow a consistent epideictic agenda throughout the poem.

\section{Praising through Intertext}

As will be illustrated with reference to his reception of Lucan's Pharsalia and Vergil's Aeneid, Liefer systematically employs allusions and citations to turn his epic into a laus urbis. His most important strategy is to establish a correlation between Stralsund and Massilia or Troy respectively, thereby having the Sunnonians either equal or exceed the virtues of their famous role models.

The following analysis focuses on two exemplary passages of the Bellum Sundense with their respective source text $-B S$ 899-915 and

but the author was well-known and his text had been used for the composition of centones prior to Liefer: see R.F. Glei, "Aufstand gegen den Textsinn. Zum Lucan-Cento des Pierre Chrétien (1588)", in C. Walde (ed.), Lucans Bellum civile. Studien zum Spektrum seiner Rezeption von der Antike bis ins 19. Jahrhundert (Trier, 2009), 221-254.

${ }^{10}$ S. Prete (ed.), Decimi Magni Ausonii Burdigalensis Opuscula (Leipzig, 1978).

${ }^{11}$ Glei 2009 (as in n. 9), at 231. 
Phars. Book 3, as well as BS 1166-1210 and Aen. Book 2 - that were selected for the fact that they are representative of the spectrum of Liefer's literary technique. Not only are Vergil and Lucan the canonical authors Liefer most frequently refers to, but the passages in question also reflect themes and structures dominant throughout his work. The battle for Stralsund culminates in a siege modelled upon Caesar's march against Massilia, allowing illuminating insights into Liefer's way of introducing and representing his main characters. ${ }^{12}$ Liefer's "Laocoön passage", on the other hand, may stand in for the parts of the poem either preceding or following the battle as such. In the aftermath of the siege, we can observe Liefer bringing his source text even more to the foreground and thus more heavily relying on the literary knowledge of his audience.

\section{Liefer and Lucan}

The first paragraph under investigation (BS 899-915) is closely modelled upon Phars. 3.300-306 and 3.355-358. ${ }^{13}$ The general context of both passages is the same: Wizlaus and his allies lay siege to the city of Stralsund (BS 899-957) on the one hand, and Caesar marches against Massilia on the other (Phars. 3.300-450).

In the first step of our analysis, we will investigate the dynamics between Caesar and Massilia as represented in the Pharsalia, so as to assume Liefer's point of view at the time of his poem's composition. Subsequently, in closely comparing the text of the Bellum Sundense to its literary role model, we will point out significant modifications and assess their epideictic effect.

In Lucan, just prior to the lines under investigation, Caesar leaves the walls of trembling Rome ("trepidantis moenia Romae", 3.298) and arrives at the gates of Massilia. The town is described as follows:

12 These are questions much debated in modern scholarship on Lucan. See, e.g., the recent discussions in M. Kersten, Blut auf Pharsalischen Feldern. Lucans Bellum civile und Vergils Georgica (Göttingen, 2018), 41-154 ("Caesar und die Umwelt") and 155-216 ("Pompeius, Cato und der Tod"), and in K. Ludwig, Charakterfokalisation bei Lucan. Eine narratologische Analyse (Berlin, 2014), 85-155.

${ }^{13}$ D.R Shackleton Bailey (ed.), M. Annaei Lucani De bello civili libri X (Stuttgart, 1988). 
cumque alii famae populi terrore paverent 300

Phocais in dubiis ausa est servare iuventus non Graia levitate fidem signataque iura, et causas, non fata sequi. Tamen ante furorem indomitum duramque viri deflectere mentem pacifico sermone parant $[\ldots]$

Though other peoples cowered at the terror of his name, the Phocaean warriors, with steadfastness rare in Greeks, dared to be faithful to their solemn compacts in the hour of danger, and to follow right rather than fortune. But first they tried by peaceable argument to turn aside the reckless rage and stern heart of Caesar. ${ }^{14}$

The Massilians' bravery is introduced against the backdrop of more timorous peoples, not least the people of Rome that Caesar left behind. Whereas others are terrified even at Caesar's reputation as such (3.300), Massilia is represented as a city of radically different characteristics. Its very appellation (Phocais) - harking back to Phocaea in Asia Minor, the mother city of Massilia - links the town to a people renowned for its moral qualities, its cultural achievements and unswerving loyalty to the Roman state. ${ }^{15}$ Portraying Massilia as the continuation of Phocaean virtue, Lucan's word choice implies that Caesar's attack against the city cannot be justified. Contributing to this effect, the Massilian youth are said to distinguish themselves, inasmuch as they dare to prove their loyalty ("ausa est servare [...] fidem") and to replace Greek levitas with Roman gravitas. ${ }^{16}$ All in all, the description not only serves to commend Massilia but also to point out the qualities which Rome so inauspiciously lacks.

Even before the Massilians try to prevent the attack in a peaceful manner ("pacifico sermone", 3.305), Lucan's lines hint at the fact that the enemy's attitude renders such efforts completely hopeless ("furorem indomitum" and "duramque viri mentem", 3.303-304). Caesar's anger, his most prominent characteristic throughout the Pharsalia, cannot be restrained by any rational argument. ${ }^{17}$

\footnotetext{
14 We follow the translation of the Pharsalia by J.D. Duff (ed., tr.), Lucan, The Civil War (Cambridge, MA, 1928).

15 Cf. Cic. Flac. 63; Liv. AUC 37.54.21; Sil. Pun. 15.171; and V. Hunink (ed.), M. Annaeus Lucanus. Bellum Civile, Book III. A Commentary (Amsterdam, 1992), ad loc.

${ }^{16}$ Cf. Cic. Flac. 19, 24; and Hunink 1992 (as in n. 15), ad loc.

${ }^{17}$ Cf. Lucan. Phars. 1.146, 2.493, 3.136, 3.439, 8.134, 8.643, 8.565.
} 
Keeping these findings in mind, we may take into account the correspondent passage of the Bellum Sundense and point to differences between the source text and its seventeenth-century adaptation:

Quando urbes aliae famae terrore paverent

horrendi belli, in dubiis servare iuventus 900

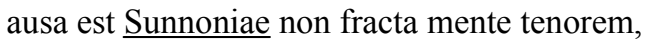
indubiamque fidem, iurando iuraque firmata, et causas non fata sequi; tamen ante furorem indomitum duramque ducum deflectere mentem pacifico sermone parant $[\ldots]$

Though other cities cowered at the terror of a cruel war, the youth of Stralsund, with extraordinary bravery, dared to follow their track in the hour of danger, to be faithful to their solemn compacts and to follow right rather than fortune. But first they tried by peaceable argument to turn aside the reckless rage and stern heart of the leaders.

cumque alii famae populi terrore paverent 300

Phocais in dubiis ausa est servare iuventus non Graia levitate fidem signataque iura, et causas, non fata, sequi. Tamen ante furorem indomitum duramque viri deflectere mentem pacifico sermone parant $[\ldots]$

A number of significant changes to the text of the Pharsalia may be observed. Most obviously, Liefer replaces Phocais with Sunnonia (BS 901), thereby transferring the positive image of Lucan's Massilia to the city of Stralsund and its citizens. On a similarly basic level, we may note that Liefer leaves out details peculiar to the historical background of the Pharsalia and thus turns his role model's lines into more universal statements on warfare and the terrors associated with it. Whereas in Lucan, entire peoples are frightened at Caesar's notoriety - Caesar being the ruthless embodiment of war itself - the Bellum Sundense is much more open, as it depicts unspecified cities afraid of the very idea of war and suffering (899-900).

On closer inspection, Liefer's generalizations not only serve to adapt his source text to a fourteenth-century context but also to realise his epideictic ambition. This twofold function may be exemplified with reference to his substitution of "alii [...] populi" (Phars. 3.300) with "urbes aliae" (BS 899). On the one hand, of course, the siege of 1316 
required a different wording, as Stralsund was just one town - not an entire people - fighting against its attackers. On the other hand, since contemporary readers may be assumed to have known the outcome of the Margrave War as well as that of the Roman Civil War of 49-45 BCE, the Bellum Sundense achieves a sense of amplificatio through intertextuality: while both Massilia and Stralsund dared to engage in battle with powerful enemies, Stralsund was the only one of the two that actually won the conflict. In this sense, Liefer's "urbes aliae" emphasises the fact that one small city alone was capable of fighting back the enemies' attack.

In addition to underlining Stralsund's bravery and ultimate success, Liefer modifies his source text so as to increase the scale of the threat posed to the city: in line 904, he replaces "viri" with "ducum", making clear that not one but two leaders laid siege to Stralsund, both of whom - that is Eric and Wizlaus - express the fierce anger associated with Caesar ("indomitum duramque [...] mentem", BS 904 and Phars. 3.304).

Another instance of this literary technique may be observed a few lines later. In Lucan, Massilian envoys implore Caesar to respect the city's neutrality and demonstrate their readiness to die for the sake of liberty (3.307-355). As soon as they have finished their speech, however, the text makes clear that Caesar is determined to reduce Massilia to ashes:

Sic Graia iuventus 355

finierat, cum turbato iam prodita vultu ira ducis tandem testata est voce dolorem:

"Vana movet Graios nostri fiducia cursus."

Thus the Greeks ended speaking, and Caesar's wrath, betrayed already by his clouded countenance, at last proved his resentment by spoken words: "These Greeks trust in my haste, but they trust in vain."

Caesar's anger ("ira") refers back to the outset of the envoys' speech ("furorem indomitum", 3.303-304), which already anticipated their attempt's ultimate failure. His unjust resentment is expressed through his words as well as his facial expressions ("turbato iam prodita vultu" and “dolorem"), pointing to Caesar's lack of rationality as one of the most serious dangers posed to Massilia. ${ }^{18}$

${ }^{18}$ Cf. Hunink 1992 (as in n. 15), ad loc. and ad 3.133. 
Again, Liefer's version of his source text exhibits significant modifications. After a short summary of the envoys' appeal (907-911), Stralsund receives the enemies' response:

Proficiunt tamen haud quicquam, verum acrius omnes

ira incenduntur. Wislaus causa caputque

totius belli testatur voce furorem:

"Vana movet vestri fiducia perdita valli"

Still, they did not achieve anything, but that everyone's anger grew even fiercer. Wizlaus, cause and head of this entire war, gave proof of his rage by his word: "Your trust in your wall is hopeless and in vain."

In the first place, Liefer further pursues his strategy of generalizing the ideas given in Lucan, as he applies Caesar's ira (Phars. 3.357) not to one but to all of Stralsund's enemies: "omnes ira / incenduntur" (BS 912-913). Subsequently, however, he encourages his readers to identify Lucan's Caesar with Wizlaus, leader of the Rugians, alone. Wizlaus' epithet, "causa caputque / totius belli", presents him as the true embodiment of war, passing over - for the time being - the equally important role of king Eric during the battle for Stralsund. Even more so, Wizlaus' status is made apparent on the intertextual level, taking up Caesar's part in speaking up against the envoys' appeal. Liefer's modification of his source text, that is changing "dolorem" (Phars. 3.358) to "furorem" (BS 914), may be seen to render Wizlaus, in a way, more "Caesarean" than Caesar himself. After all, furor - more so than dolor - lends itself to being tied in with ira, thus further characterizing Wizlaus as a commander devoid of rationality.

On another note, Liefer changes the details of Caesar's response to the envoys' peaceful approach: whereas Caesar had referred to the Massilian's misplaced trust in his haste ("vana [...] cursus", Phars. 3.359), Wizlaus expresses his disdain toward the city walls ("vana [...] valli", $B S$ 913). This modification - again, in combination with the fact that Stralsund's fortifications actually held off the attackers - is not only consistent with the overall importance of the city walls in Liefer's poem, ${ }^{19}$ but is also in line with the ancient tradition of laudes urbium, where the praise of walls had been a stock element at least since the first century CE. ${ }^{20}$

${ }^{19}$ BS 38-42, 694-695, 734, 798, 842, 930-934, 965-966, 1147, 1423; cf. BS pr. 42-57.

20 See e.g. Quint. Inst. 3.7.26; and C.J. Classen, Die Stadt im Spiegel der Descriptiones 


\section{Liefer and Vergil}

A markedly different type of strategic city praise can be identified in the second paragraph central to this study, a passage closely modelled upon the beginning of the second book of the Aeneid. ${ }^{21}$ In Vergil's text, Dido asks Aeneas to relate the story of the sack of Troy (1.753-756). He begins to tell her of the wooden horse which the Greeks claimed to be an offering to the gods, but which in fact bore in its hollow belly the best of the Greek warriors (2.18-19). The rest of the Greek troops were hiding in a bay nearby (2.24), while the Trojans thought they had left for their homeland ("nos abiisse rati", 2.25). As Aeneas starts his account with reference to the Greeks' treachery and to the Trojans' credulity, Troy's eventual - and potentially preventable - destruction is at the heart of his tale from its very beginning. In the following lines, Aeneas recounts how the Trojans left their city to inspect the places where the enemies had camped (2.26-30). Finding the wooden horse, they disagreed about its nature and the treatment it deserves (2.31-39). Laocoön warned against trusting the Greeks and their alleged gifts (2.40-49), even hurling his spear in the horse's side, but ultimately failed to change his comrades' minds (2.50-54). With hindsight, Aeneas asserts that the Trojan citadel could still be standing, if only they had heeded Laocoön's warning ("si fata deum, si mens non laeva fuisset", 2.54-56).

Having reached the end of the battle for Stralsund, Liefer's description heavily relies on the Vergilian passage outlined above. After the enemies have returned to Denmark and Sweden respectively (BS 11401148), ${ }^{22}$ the Sunnonians leave their city and inspect the places so recently deserted (1166-1210):

Iam postquam hostiles acies terraque marique

discessere, omnis solvit se Sundia luctu,

panduntur portae, iuvat ire, atque hostia castra

desertosque videre locos, litusque relictum,

talibus et dictis sese solantur amici;

hic procerum manus, hic saevus Wislaus agebat,

und Laudes urbium in der antiken und mittelalterlichen Literatur bis zum Ende des zwölften Jahrhunderts (Hildesheim, 1980), 26.

${ }^{21}$ R.A.B. Mynors (ed.), P. Vergili Maronis Opera (Oxford, 1969).

${ }^{22}$ Liefer $(B S 1143)$ calls Knud Porse, Duke of Halland, a Belga, which probably goes back to a misspelling of Holland for Halland in one of Liefer's sources. See Kruske 2004 (as in n. 1), 116 (n. 113) and 171. 
classibus hic locus, hic acies certare solebant, pars stupet in castris, vinum frugesque dapesque innumeri generis mensas, subsellia, currus, pars abiisse rati, pars constituere latere hostes ad tempus reduces, urbique futuros longe quam fuerant graviores ante relictae. Scinditur incertum studia in contraria vulgus. Primus ibi ante omnes magna comitante caterva vir meritis gravis, et nulli pietate secundus, ex urbe exclamat veniens: "Procul este, prophani, ite procul, miseri, quae tanta insania, cives? Creditis avectos hostes? Aut ulla putatis dona carere dolis procerum? Sic notus Ericus sic et Wislaus nostrae infensissimus urbi hostis? Sicque duces reliqui? Ne fidite, nostrum exitium quaerunt, ideoque haec dona tulerunt, his ut inescantes vino somnoque sepultam invadant securam urbem terraque marique: Hostes querceto aut tecti occultantur in isto aut ratibus simulare fugam voluere per aequor, aut aliquis latet error, eis ne credite, cives! Quicquid id est, hostes timeo vel dona ferentes." Sed postquam expertum est hostes abiisse, fugaque unumquemque suas sedes petiisse paternas, [...]

Vota deo solvunt, urbes qui munit et hostium infringit vires, docet et qui brachia ahenum tendere in adversos arcum, qui scandere muros adiuvat, et prohibet, turbat qui sede potentes, et sibi fidentes humiles extollit, et ipsos principibus magnisque viris assidere mandat.

1166 nos abiisse rati et vento petiisse Mycenas Aen. 2.25 || 1167 ergo omnis longo solvit se Teucria luctu 26|| $\mathbf{1 1 6 8}$ et Dorica $27 \| \mathbf{1 1 6 9}=28|| \mathbf{1 1 7 1}$ hic Dolopum manus, hic saevus tendebat Achilles 29 || $\mathbf{1 1 7 2}$ acie 30|| $\mathbf{1 1 7 3}$ pars stupet innuptae donum exitiale Minervae 31|| $\mathbf{1 1 7 4}$ et molem mirantur equi $32 \|$ 1178-1179 = 39-40 || 1180 Laocoon ardens summa decurrit ab arce $41 \| \mathbf{1 1 8 2}$ et procul o miseri $42\|\mathbf{1 1 8 3}=43\| \mathbf{1 1 8 4}$ dolis Danaum? sic notus Ulixes? 44 || $\mathbf{1 1 8 5}$ aut hoc inclusi ligno occultantur Achivi 45 || 1186 aut haec in nostros fabricata est machina muros 46|| 1187 inspectura domos venturaque desuper urbi 47|| 1192 equo ne credite, Teucri 48 || 1193 timeo Danaos et dona 49 || 1207 et, si fata deum, si mens non laeva fuisset 54 || 1208 impulerat ferro Argolicas foedare latebras 55 || 1209 Troiaque nunc staret, Priamique arx alta maneres 56. 
Not long after the enemy troops withdrew from land and sea, the whole city of Stralsund was released from sorrow, the gates were opened, it was a joy to go and see the hostile camp, the deserted site and the abandoned shore. [1170] Friends comfort each other with these words: "Here the nobles stayed, here cruel Wizlaus, here lay the fleet, here they used to meet us in battle." Some were amazed at the camp, at the wine and crops and meals of innumerable kinds, at benches and chariots. [1175] Some believed the ships had departed, others supposed the enemies were hiding and waiting to return at the right time and to harm the city in the future much more than when they had left it. The crowd, uncertain, was split by opposing opinions. Then, as the first before all, [1180] a man of great merit and of outstanding piety comes out of the town, shouting: "Stand far away, you profane ones! Go away, you unhappy citizens, what great madness? Do you think the enemies have sailed away? Or do you think any of the rulers' gifts are free of treachery? Is that Eric's reputation and [1185] Wizlaus's, our city's bitterest enemy? And the other leaders likewise? Do not trust them! They want our destruction; that is why they have brought these gifts: to entice us with them and to invade our city on land and sea while it feels safe, as it is buried in wine and sleep. [1190] The enemies are hiding, protected in this oak forest, or they wanted to pretend to be fleeing on the sea in their ships; or some other trick is hidden. Do not trust them, citizens! Whatever it is, I'm afraid of enemies, even those bearing gifts." But after they had made sure that the enemies had left [1195] and that every single one of them had fled to their homeland, [...] [1207] They prayed to God, who strengthens towns and weakens the power of enemies, and who teaches arms to bend the bronze bow against foes, who either assists or prevents the ascension of walls, who agitates the mighty on their throne, and who elevates the humble trusting in him, and instructs them to sit with the leaders and powerful men.

For the comparison of the passage of the Bellum Sundense with its source text, we will not elaborate on small adaptions that make Vergil's lines fit the poem's fourteenth-century context, as this type of modification has already been discussed with regard to Lucan. Instead, we will focus on the overall effect brought about by Liefer's adaptation of the Aeneid.

Most obviously, prominent figures of the Margrave War take up the roles of heroes before Troy: Wizlaus holds the position of Achilles (1171) and Eric that of Odysseus (1184) by means of a simple substitu- 
tion of names. In the same vein, of course, the besiegers of Stralsund are identified with the Greeks, while the Sunnonians play the part of the Trojans. Yet, there is no simple analogy between Liefer's adaptation of Vergil and what we have observed in the section on Lucan.

With most of the Aeneid's roles occupied, one significant mismatch between the Bellum Sundense and its source text becomes painfully obvious: the Trojan horse, which is clearly at the centre of the Vergilian passage, has no equivalent in Liefer's poem. As it stands, the "gifts" spoken of by the Laocoön figure ("hostes timeo vel dona ferentes", 1193) rather awkwardly refer to the food, benches and chariots left behind by the attackers (1173-1174). On a more abstract level, the amount of lines devoted to warnings against treachery seems out of proportion, since - as would be clear to those acquainted with the Margrave War - the enemies' retreat was no deception. Furthermore, the historical facts are mirrored in the poem's narrative structure: whereas Aeneas begins his tale with references to its fatal ending and thus creates an atmosphere of uncertainty and suspense, the narrative voice in the Bellum Sundense leaves no doubt about Stralsund's victory even before the Sunnonians start suspecting some artifice of war. ${ }^{23}$

These findings suggest that the "Troy passage" is much more dependent on the audience's knowledge of Liefer's source text than the "Massilia passage" discussed above. Whereas in the case of Massilia, citations and allusions mainly served to enhance features inherent to the poem's plot, the Sunnonians' dispute on treachery would hardly function - and probably would not have been written - without the background presence of the Aeneid. The significance of his source text is further stressed by the fact that Liefer does not restrict intertextual references to Vergil's Laocoön passage, but also incorporates prominent lines from other parts of the Aeneid: the first words of the Laocoön figure ("procul este, prophani", $B S$ 1181) are clearly reminiscent of the first words uttered by the divinely-inspired Sibyl in the sixth book of the Aeneid ("procul, o procul este, profani", 6.258). Secondly, BS 11881189 ("vino somnoque sepultam / invadant securam urbem") correspond to Aen. 2.265 ("invadunt urbem somno vinoque sepultam"), that is

${ }^{23} B S$ 1137-1144, at 1137-1138: "Inclinant iam fata ducum, nec iam amplius anceps / belli casus erat" (= Phars. 3.752-753), "The fortunes of the leaders were no longer evenly balanced, and the issue of the fight was no longer doubtful." 
Aeneas' description of the crucial moment when the Greek heroes leave the horse to bring about Troy's destruction.

Another crucial mismatch between the Aeneid and the Bellum Sundense is the people's reaction to the words of the Laocoön figure. His warnings, fatally ignored by the Trojans, are in fact heeded by the Sunnonians. It is only after they have made sure of the enemies' flight to their homelands, Liefer sees fit to point out (1194-1195), that they start a counter-attack to free the cities still held by the foes (1196-1206). Again, this emphasis on the Sunnonians' caution seems uncalled for by the plot of the Bellum Sundense. With the Aeneid in mind, however, the inhabitants of Stralsund display exemplary prudence and thus prove themselves worthy of their victory. Their actions and moral character, Liefer seems to suggest, is qualitatively different from the Trojans. Not only do they share their bravery, but they also exceed them in humility and in their devotion to the one god, who decides over matters of war and peace (1207-1212).

\section{Conclusion}

The aim of this paper was to show how Jakob Liefer uses references to classical literature to turn his epic Bellum Sundense into a laus urbis. It has been observed that praising Stralsund through intertext functions by means of at least three different techniques. (1) By making Stralsund the central topic of an epic poem, Liefer puts the city on the same level as Massilia and Troy. He embellishes his text with citations of esteemed authors to transfer positive or negative associations to the characters and places featuring in his work. (2) Apart from the substitution of names, that is the redefinition of literary roles, Liefer's changes to his source texts routinely include quantitative amplificationes, which increase the perceived scale of the threat posed to Stralsund. (3) In many regards, modifications are of a qualitative rather than of a quantitative nature, as the Sunnonians are represented as surpassing the accomplishments of their ancient role models.

While all these techniques are based on the readers' knowledge of classical literature, it has been noted that some of the complimentary effects produced by the Bellum Sundense are more heavily dependent on intertextuality than others. It is worth pointing out that this finding ties in with the information given in the margins of Liefer's text, suggesting 
that his poem was aimed at a broad audience. Full appreciation of the author's literary technique could only be expected from the learned elite, that is the members of the city council addressed in the preface. Those less acquainted with the classics were made aware of the poem's intertextual borrowings by means of the explicit references to the authors cited. Lastly, recipients having but a limited understanding of Latin could follow the work's plot with the help of the summaries in the vernacular.

On both the intra- and intertextual level, the poem's overall message appears to be that the people of Stralsund emerged victorious from the Margrave War owing to their complete trust in the Christian god. In the case of the Pharsalia as well as the Aeneid, Liefer has the Sunnonians take the losing side of the warring parties involved, and essentially attributes the conflict's positive outcome to Christian piety. It is faith, after all, that made the difference and that will, it may be inferred, also save Stralsund from destruction during the Thirty Years' War. The Bellum Sundense may thus not only be read as a flattering display of gratitude to those in power but also as a strong appeal for confidence and humility directed at the less privileged social classes.

\author{
Johannes Gutenberg-Universität Mainz \\ koloebck@uni-mainz.de \\ Universität Rostock \\ paul.reichetanz@uni-rostock.de
}

